\title{
Agriculture Production and Food Security in State Number Five, Nepal
}

\author{
Prem Sagar Chapagain, PhD \\ Central Department of Geography, Tribhuvan University, Nepal.
}

*Corresponding Author: Prem Sagar Chapagain, PhD, Central Department of Geography, Tribhuvan University, Nepal. Email: ps.chapagain@gmail.com

\begin{abstract}
Agriculture is the bases of livelihood, a major sector of employment and the major source of GDP of Nepal. Nepalese agriculture is subsistence in nature and the situation of the state five is also the same. Out of twelve districts of the state, each of the six districts have less than 20 percent agricultural land of the total area of the district. Within the available agricultural land, temporary crops which primarily include cereal crops have dominated as permanent crops have covered less than five percent of the total area in most of the districts. Paddy, maize, wheat and millet are the major crops. Out of the total production of cereals, paddy share about 52 percent. In addition, major cash crops include oilseeds, sugarcane, ginger and coffee of which ginger and coffee are primarily grown in Hill districts and rest in the Tarai districts. Crop productivity is low and vary by district. The province is food secure in terms of total production. However, a few districts namely Banke, Rolpa, Pyuthan, and Nawalparasihave negative food balance.
\end{abstract}

Keywords:Agriculture, temporary crop, permanent crop, production, productivity, food security.

\section{INTRODUCTION}

Agriculture refers to rearing animals and production of crops through cultivating the soil (Mannion 1995). Importantly, it is an expression of interaction between people and environment that has evolved over a period of last 10,000 years (MacNeish 1992 cited in Robinson 2004). Agriculture is one of the most important sectors that provides employment opportunities to about 66 percent of the total population and it contributes about 30 percent in the GDP of Nepal (MoF 2017). Nepalese agriculture is primarily subsistence. However, there are several pocket areas where various cash crops and vegetables are grown for the commercial purpose. In terms of altitude, the country ranges from about 60 meters above sea level to 8848 meters, the top of the world, and it has diverse topography where various types of climates are found. In the southern belt there is tropical and sub-tropical climate and with increasing altitude climatic zone also change having temperate, and alpine climate. The climatic variation has provided both opportunities and constraints for production of different types of cereal crops, fruits and vegetables in the different parts of the country. It is because of this diversity, the agriculture perspective plan of Nepal has broadly recommended southern Tarai for cereal production, Middle Hills for horticulture and Mountain region for livestock farming (APROSC 1995).

Although Nepal is primarily an agrarian country, agriculture development is at its earlier stage in terms of mechanization, application of various agricultural inputs and availability of irrigation. Irrigation is one of the major constraints as agriculture depends on monsoon rain that takes place from June to September. The winter crops face severe water shortage and draught at various places of the country. Agro-forestry is the common practice where forestry sector provide fodder, litter to livestock whereas agriculture land gets manure from livestock. Each household has livestock for draught power, milk and other animal products. Animal primarily ox and he buffalo are used to plough filed. Because of these situation, the major challenges of the Nepalese agriculture are very low productivity, limited attempt for commercialization of crops, poor extension services, and little interest of private sector on agriculture, massive out-migration of agriculture labor and high fragmentation of land.

The increasing challenges to agriculture sector has severely affected food security in the country. Food security is generally refers to have access to the food that meets their daily caloric and 
nutritional requirements. As Subedi and KC, (2001) claim that food security is a fundamental right and government responsibility and it is like education, health, and public security. The present constitution of Nepal has declared food as the fundamental right of people too. While in the case of Nepal, farmers generally sell food immediately after harvesting and they usually get lower price. They do not have proper storage facility and space to store for longer period. While in the winter month they face food shortage and compel to buy food in higher price. It is thus, production might be sufficient at district or regional level but they even face food insecurity. Thus, this paper aims to examine the situation of agricultural land, production of various crops and food security situation of the twelve districts of State Number Five of Nepal.

\section{MethodS AND MATERIALS}

State number Five is located in the western and mid-western part of the country. It is one of the seven states in Nepal. There are 12 districts of Nepal in this state.The state shares about 17 percent of the total population of the country.Out of 12 districts, six districts in Tarai and Inner Tarai (Nawalparasi, Rupandehi, Kapilvastu, Banke, Bardiya and Dang) and remaining seven districts are in Hill region. The Tarai and Inner Tarai districts share about 72 percent of the total population of the state.Rupandehi district alone shares about 20 percent population followed by Kapilvastu with about 13 percent population of the state. Rukum shares about one percent population of the state followed by Aarghakhanchi (4.4\%) and Rolpa (5.1\%) (CBS 2012). In totality, state five covers about 13 percent area and 17 percent of the total population of the country. In terms of the boundary, India is in the southern part and state number 3 and four in the east and north east, state 6 in the north and state 7 in the west (Figure 1).

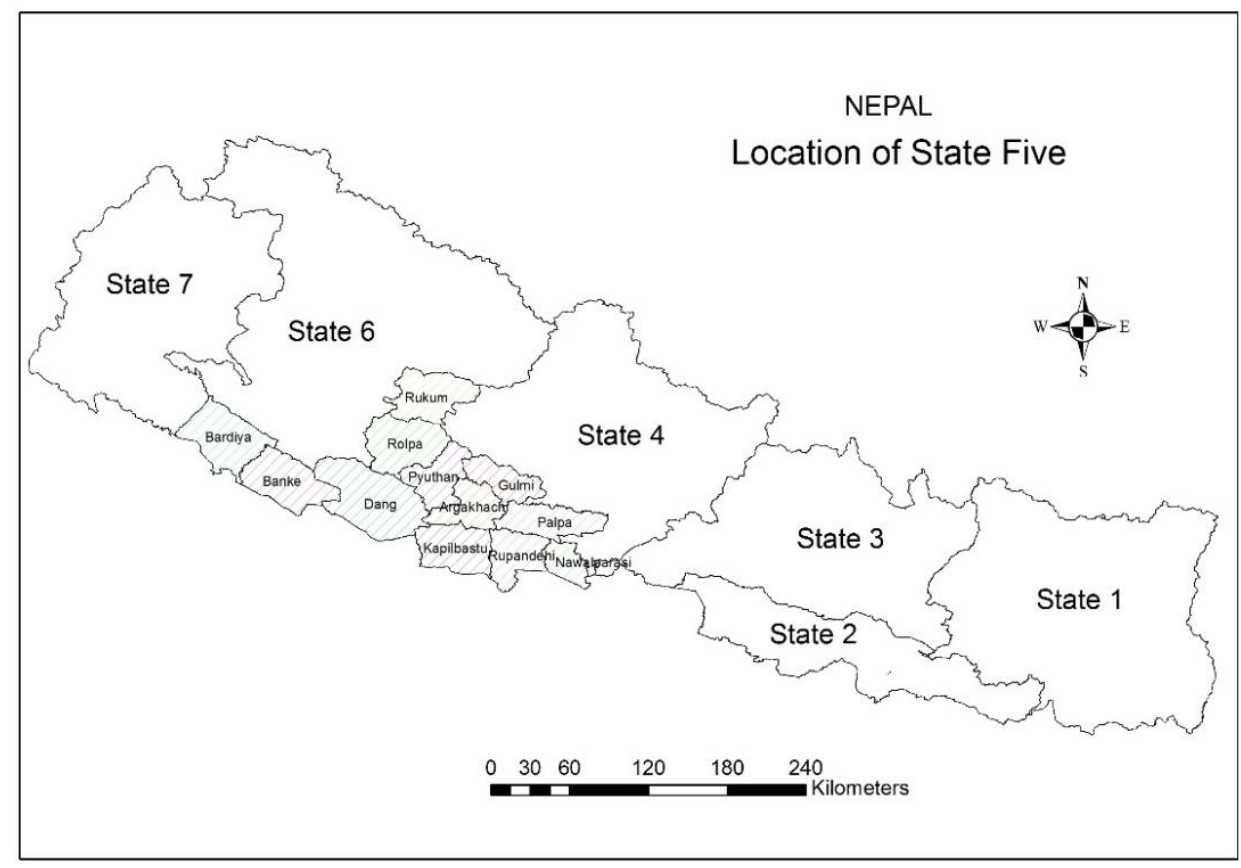

Figure 1.Location of province number five, Nepal.

The study is based on the secondary data. The major sources of data are the agriculture census of 2011-12 (CBS 2013) and the agriculture statistics of 2015/16 published by Ministry of agriculture (MoAD 2017) in 2017. District wise agricultural land by types of crops is collected from agriculture census. According to agricultural census2011\&12, agricultural land includes area under temporary crops, area under temporary meadows, area under temporary fallow, area under permanent crops, pasture and woodland. Temporary crops include seasonal or single year crops that include paddy, maize, millet, wheat, barley while multiyear corps is refereed as permanent crops. Land area under meadows, fallow land, pasture and woodland is very limited. It is thus, area under temporary crops and permanent crops has considered for analysis. Food security has four dimensions - availability, access, utilization and stability. The issue of food security is multidimensional as it differs by countries, social groups and time. FAO (2010) has grouped these issues into three groups, 1) overall socio-economic, political and natural environment, 2) performance of the food economy, and 3) household level food security influenced by livelihood assets and activities, care practices, and health and sanitation conditions. Although there are four dimensions of food security, it has only focused to 
examine the situation of food availability here and focused to major crops, their production and productivity by district. These data are collected from recently available agricultural statistics (MoAD 2017). The information of Nawalparasi and Rukum is not available as these two districts in this state is provisioned as per the new administrative structure as per the constitution of Nepal 2015 and thus agricultural production data is not available.

\section{Situation of Agricultural LAND Availability}

At national level, bout 17 percent land is agricultural land. As mentioned above, agricultural land consists of land under temporary crops, permanent crops, fallow, pasture and wood land. The Tarai districts of the state has larger area under agricultural land. The two districts particularly Rupandehi, and Kapilvastu each has60,000 to 70,000 hectares of agriculture land. The hill districts such as Gulmi, Palpa and Aarghakhanchi each has also 30,000 to 40,000 hectares of agricultural land. The larger area of temporary crops such as paddy, maize, wheat, millet, and oil seeds production is in Rupandehi and Kapilvastu as these districts shares about 48 and 34 percent of the total area of the districtunder the agricultural land respectively. Rolpa, Banke and Palpa districts have lower percentage of agricultural land area. However, permanent crops' area is relatively higher in Gulmi and Aarghakhanchi district (Table 1)

Table 1.Total agricultural land, area under temporary and permanents crops (area in ha)

\begin{tabular}{|c|c|c|c|c|c|c|}
\hline District & $\begin{array}{l}\text { Total agri. } \\
\text { land }\end{array}$ & $\begin{array}{l}\% \text { Agri. land (to } \\
\text { total district area) }\end{array}$ & $\begin{array}{l}\text { Temp } \\
\text { crop land }\end{array}$ & $\begin{array}{l}\text { Temp crop area (\%to } \\
\text { district total area) }\end{array}$ & $\begin{array}{l}\text { Permanent } \\
\text { crop land }\end{array}$ & $\begin{array}{l}\text { \% Permanent crops (to } \\
\text { district total area) }\end{array}$ \\
\hline Gulmi & $40,904.20$ & 35.60 & $18,813.70$ & 16.4 & $22,090.50$ & 19.2 \\
\hline Palpa & $29,970.60$ & 21.83 & $20,523.20$ & 14.9 & $9,447.40$ & 6.9 \\
\hline \multicolumn{7}{|l|}{ Nawalparasi } \\
\hline Rupandehi & $71,119.50$ & 52.29 & $65,793.40$ & 48.4 & $5,326.10$ & 3.9 \\
\hline Kapilvastu & $64,548.70$ & 37.14 & $59,906.00$ & 34.5 & $4,642.70$ & 2.7 \\
\hline Aarghakhanchi & $31,596.60$ & 26.48 & $16,135.10$ & 13.5 & $15,461.50$ & 13.0 \\
\hline Pyuthan & $25,808.90$ & 19.72 & $18,022.40$ & 13.8 & $7,786.50$ & 5.9 \\
\hline Rolpa & $24,853.00$ & 13.23 & $19,396.70$ & 10.3 & $5,456.30$ & 2.9 \\
\hline \multicolumn{7}{|l|}{ Rukum } \\
\hline Dang & $61,649.10$ & 20.86 & $55,387.40$ & 18.7 & $6,261.70$ & 2.1 \\
\hline Banke & $44,017.60$ & 18.84 & $41,271.80$ & 17.7 & $2,745.80$ & 1.2 \\
\hline Bardiya & $47,165.60$ & 23.29 & $44,228.80$ & 21.8 & $2,936.80$ & 1.5 \\
\hline National total & $2,522,519.90$ & $17.14+$ & $2,123,173$. & $14.43+$ & $168,450.10$ & $1.14+$ \\
\hline
\end{tabular}

Note: Data of Rukum and Nawalparasi is not available. + Percent to total area of the country.

Source: Agriculture census, 2011/12.

\section{Production and productivity of major crops}

Paddy, Maize, wheat and millet are the major cereal crops of the state. The total production of those crops is 1439898 metric tons in 2015/16. Paddy and maize are the major production of hill districts where as paddy and wheat are the major production of Tarai districts. Out of total major cereal production, paddy shares about 52 percent of the total production of these major crops followed by wheat $(26.8 \%)$ and maize $(20.1 \%)$. At the district level, one fourth of the total cereal production is from Rupandehi district. Similarly, Kapilvastu district shares about 15 percent of the total production followed by Dang (14\%), and Banke district (11\%) (Table 2, Figure 2).

Table 2.Production of major crops by district, 2015/16.

\begin{tabular}{|l|r|r|r|r|r|r|}
\hline \multirow{2}{*}{ District } & \multicolumn{2}{|c|}{ Major crops (production in Metric Tons (MT)) } & \multirow{2}{*}{ Total } & \multirow{2}{*}{ \% to total of the province } \\
\cline { 2 - 5 } & Paddy & \multicolumn{1}{|c|}{ Maize } & \multicolumn{1}{c|}{ Wheat } & \multicolumn{1}{c|}{ Millet } & & 6.7 \\
\hline Gulmi & 25815 & 50674 & 17465 & 2895 & 96849 & 6.2 \\
\hline Palpa & 30266 & 42942 & 12792 & 2773 & 88773 & 6.2 \\
\hline Aarghakhanchi & 23345 & 49350 & 12952 & 3080 & 88727 & 4.6 \\
\hline Pyuthan & 23135 & 22766 & 18543 & 2190 & 66634 & 4.2 \\
\hline Rolpa & 11928 & 26830 & 20542 & 1295 & 60595 & 25.4 \\
\hline Rupandehi & 275880 & 9955 & 79380 & 55 & 365270 & 15.5 \\
\hline Kapilvastu & 128520 & 9500 & 84451 & & 222471 & 14.0 \\
\hline Dang & 123870 & 53043 & 25310 & 15 & 202238 & 11.2 \\
\hline Banke & 92725 & 18863 & 49533 & & 161121 & 6.1 \\
\hline Bardiya & 17350 & 4837 & 65033 & & 87220 & 100.0 \\
\hline Total & 752834 & 288760 & 386001 & 12303 & 1439898 & 100.0 \\
\hline \% to total & 52.3 & 20.1 & 26.8 & 0.9 & & \\
\hline
\end{tabular}

Source: Agricultural statistics, Ministry of Agriculture Development, 2015/16. 


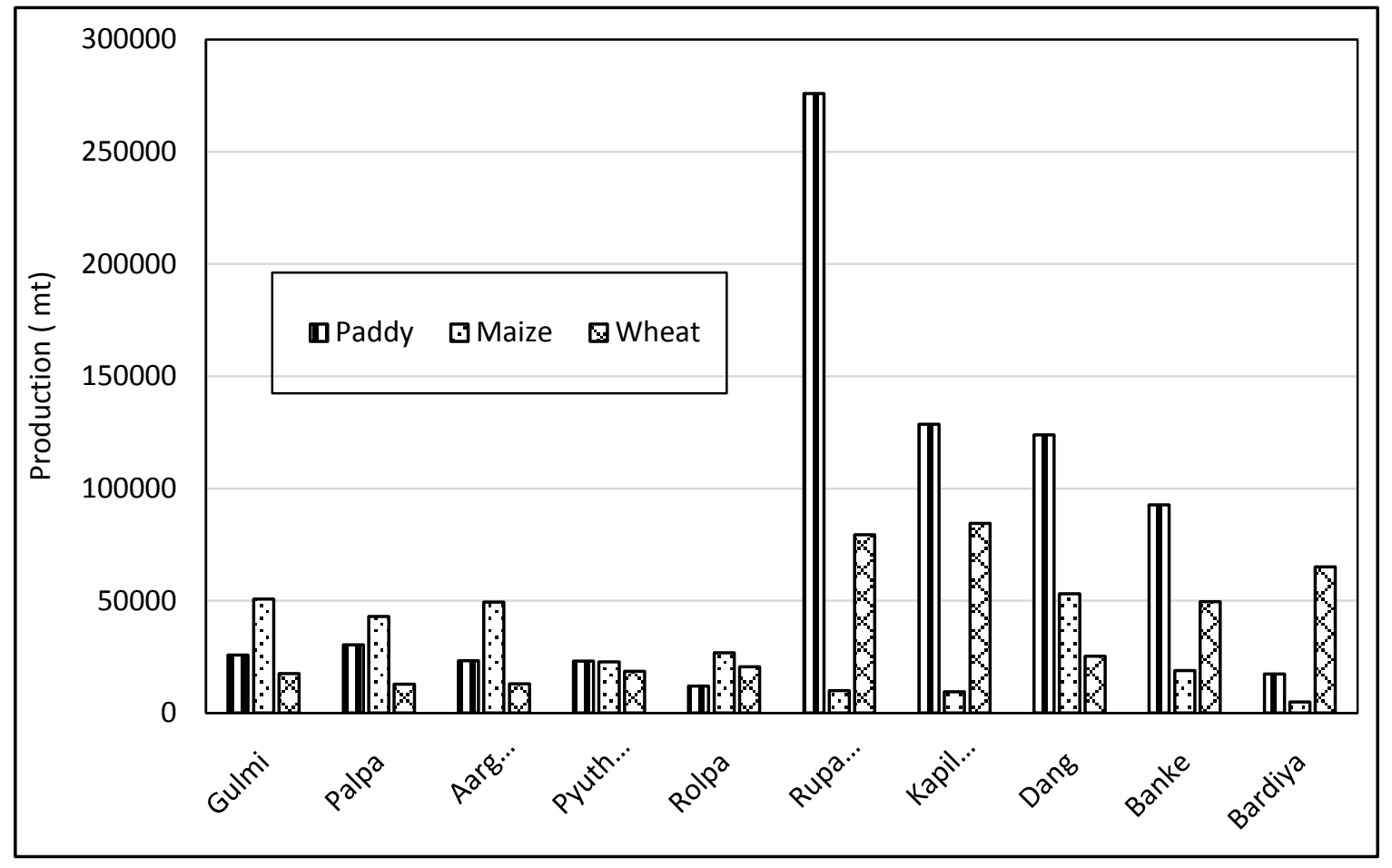

Figure 2.District wise production of paddy, maize and wheat (prod in metric ton)

The productivity of the major crops is varied by district.Paddy has highest productivity in Palpa (4438 $\mathrm{kg} / \mathrm{ha}$ ) followed by Rupandehi (398 kg/ha) andBardiya $(3577 \mathrm{~kg} / \mathrm{ha})$ district.Maize has highest productivity in Rupandehi (3982 kg/ha) followed by Bardiya $(3225 \mathrm{~kg} / \mathrm{ha})$, Kapilvastu $(3065 \mathrm{~kg} / \mathrm{ha})$ and Aarghakhanchi $(2991 \mathrm{~kg} / \mathrm{ha})$ district. The highest productivity of wheat is in Bardiya $(3475 \mathrm{~kg} / \mathrm{ha})$ followed by Kapilvastu (3024 kg/ha) andRupandehi (2700 kg/ha) district (Figure 3).

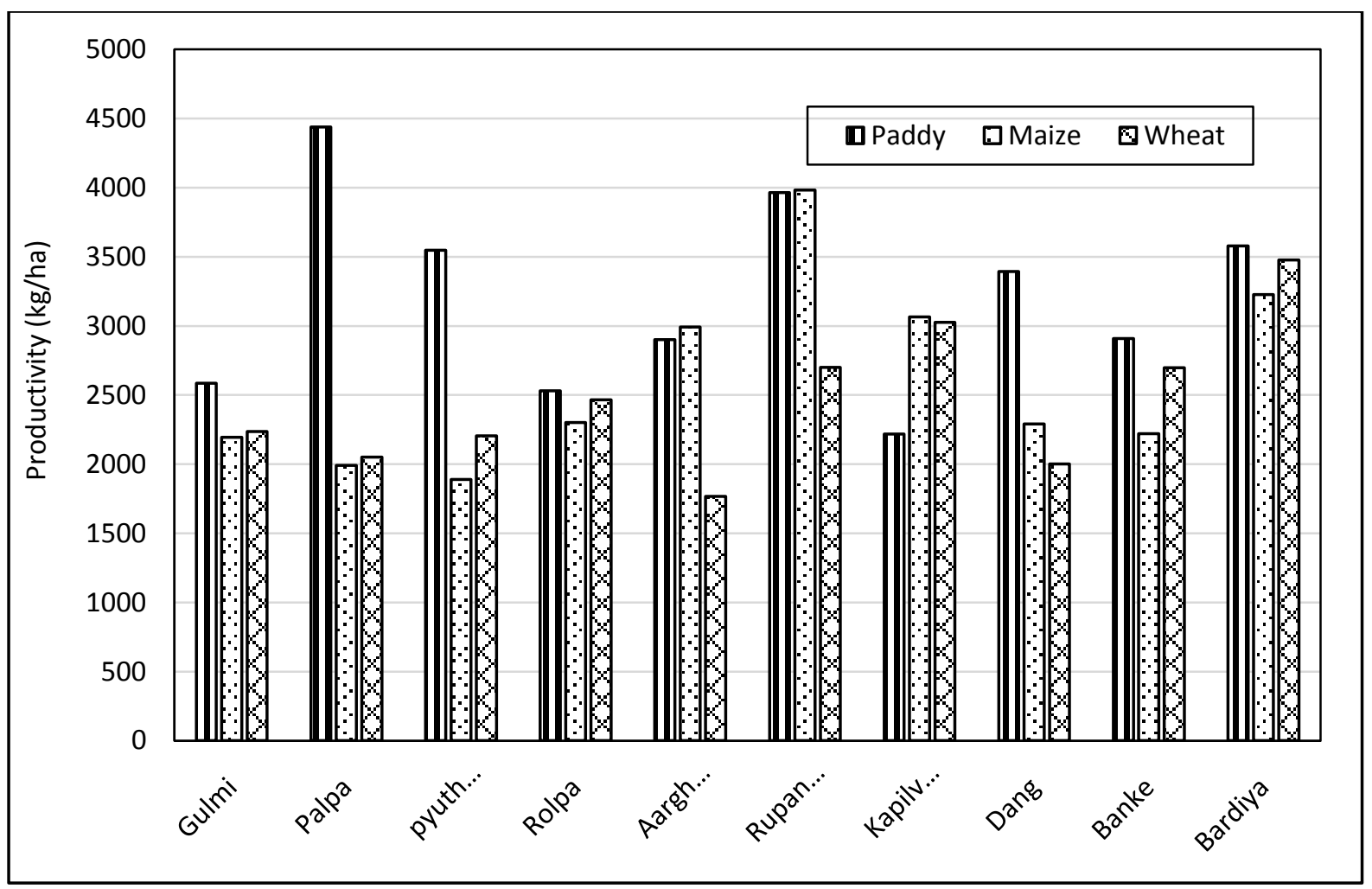

Figure 3.Productivity of major crops $(\mathrm{kg} / \mathrm{ha})$ by districts 


\section{Cash crops}

The major cash crops of the province are oilseeds, potato, sugarcane, ginger, and coffee. Orange is also produced in hill districts. This state shares 26 percent of total national production of oilseeds, about 10 percent potato, eight percent sugarcane and 12 percent of ginger. Oilseeds is mainly produced in Tarai districts i.e. Dang, Banke, Bardiya and Rupandehi. Dang district alone shares 38 percent of oilseeds of the total production of the state followed by Bardiya (18.5\%) and Banke (16\%) district.Potato is both cash crops and vegetable and it is produced in all districts.In the case of potato, about 21 percent of the total production is shared by Bardiya district. It is followed by Rupandehi (20.6\%), Kapilvastu (13.3\%) and Dang (12\%).Sugarcane is produced in Rupandehi and Kapilvastu.Kapilvastu has exclusive domination in sugarcane production as it shares about 90 percent of the total production of the state. Ginger is primarily produced in Palpa, Aarghakhanchi and Dang districts. Palpa alone produces about 45 percent of the total production of the state (Table 3 ).

Table 3.Major cash crops production (2015/16)

\begin{tabular}{|c|c|c|c|c|c|c|c|c|c|c|c|}
\hline \multirow[b]{2}{*}{ District } & \multicolumn{3}{|c|}{ Oilseed } & \multicolumn{3}{|c|}{ Potato } & \multicolumn{2}{|c|}{ Sugarcane } & \multicolumn{3}{|c|}{ Ginger } \\
\hline & Area & Prod & $\%+$ & Area & Prod & $\%+$ & Prod. & $\%+$ & Area & Prod & $\%+$ \\
\hline Gulmi & 567 & 540 & 0.99 & 475 & 6607 & 2.45 & 1949 & 0.56 & 332 & 3181 & 9.58 \\
\hline Palpa & 1236 & 1136 & 2.08 & 730 & 7523 & 2.78 & 500 & 0.14 & 1260 & 14853 & 44.73 \\
\hline Rupandehi & 7137 & 6135 & 11.22 & 3930 & 55641 & 20.59 & 18800 & 5.39 & & & 0.00 \\
\hline Kapilvastu & 4423 & 4137 & 7.57 & 2515 & 36035 & 13.34 & 315000 & 90.36 & & & 0.00 \\
\hline Aarghakhanchi & 1430 & 1351 & 2.47 & 690 & 7540 & 2.79 & 220 & 0.06 & 396 & 3930 & 11.84 \\
\hline Pyuthan & 823 & 1032 & 1.89 & 894 & 14059 & 5.20 & 695 & 0.20 & 225 & 2950 & 8.88 \\
\hline Rolpa & 374 & 336 & 0.61 & 1940 & 21048 & 7.79 & 520 & 0.15 & 145 & 1740 & 5.24 \\
\hline \multicolumn{12}{|l|}{ Rukum } \\
\hline Dang & 19072 & 20988 & 38.39 & 2250 & 32500 & 12.03 & 975 & 0.28 & 280 & 5180 & 15.60 \\
\hline Banke & 9795 & 8882 & 16.25 & 2860 & 31460 & 11.64 & 2736 & 0.78 & 190 & 1140 & 3.43 \\
\hline Bardiya & 10790 & 10132 & 18.53 & 4300 & 57800 & 21.39 & 7200 & 2.07 & 25 & 230 & 0.69 \\
\hline \multicolumn{12}{|l|}{ Nawalparasi } \\
\hline Total province & 55647 & 54669 & 100 & 20584 & 270213 & 100 & 348595 & 100 & 2853 & 33204 & 100 \\
\hline National Total & 217867 & 208291 & & 197541 & 2805513 & & 4346709 & & 21870 & 271863 & \\
\hline$\%$ share of provin & 25.5 & 26.2 & & 10.4 & 9.6 & & 8.0 & & 13.0 & 12.2 & \\
\hline
\end{tabular}

+ refer to the percentage to the total of Province 5. Area in hectare (ha), production in metric ton (MT).

Source: Agricultural statistics, Ministry of Agriculture Development, 2015/16.

Besides these crops, coffee is one of the major source of cash income. The total area under coffee is 2448 hectares and total production of coffee is 486 metric tons. This state shares about 20 percent of the total national production of coffee. Gulmi, Palpa and Rupandehi are the three major districts of coffee production that produce about 34.7, 28.8, and 27.9 percent of the total production of the state respectively. In addition Pyuthan produces 9.6 percent of the total production.

\section{Situation of food security}

Agriculture is one of the main areas of income and employment. Agriculture is of subsistence in nature. In other words farmers produce for fulfilling their biological need and for limited cash for managing daily household's goods. At present the state is food sufficient in terms of production and also has food surplus at the state level. However, at district level, Banke, Rolpa, Rukum and Nawalparasi has negative food balance (Table 4, Figure 4).

Table 4.Food requirement and balance by district, 2015/16.

\begin{tabular}{|l|r|r|}
\hline \multicolumn{1}{|c|}{ District } & Food requirement (MT) & \multicolumn{1}{|c|}{ Balance (MT) } \\
\hline Gulmi & 54,730 & 12,209 \\
\hline Palpa & 51,767 & 5,942 \\
\hline Nawalparasi & 124,546 & $-12,410$ \\
\hline Rupandehi & 177,574 & 37,326 \\
\hline Kapilvastu & 112,761 & 26,502 \\
\hline Aarghakhanchi & 38,685 & 22,028 \\
\hline Pyuthan & 47,505 & $-1,730$ \\
\hline Rolpa & 46,663 & $-2,520$ \\
\hline Rukum & 44,093 & 9,363 \\
\hline Dang & 109,327 & 7,065 \\
\hline Banke & 100,366 & $-1,767$ \\
\hline Bardiya & 81,535 & 61,693 \\
\hline
\end{tabular}

Note: Data of Nawalparasi and Rukum is of before splitting these districts.

Source: Agricultural statistics, Ministry of Agriculture Development, 2015/16. 


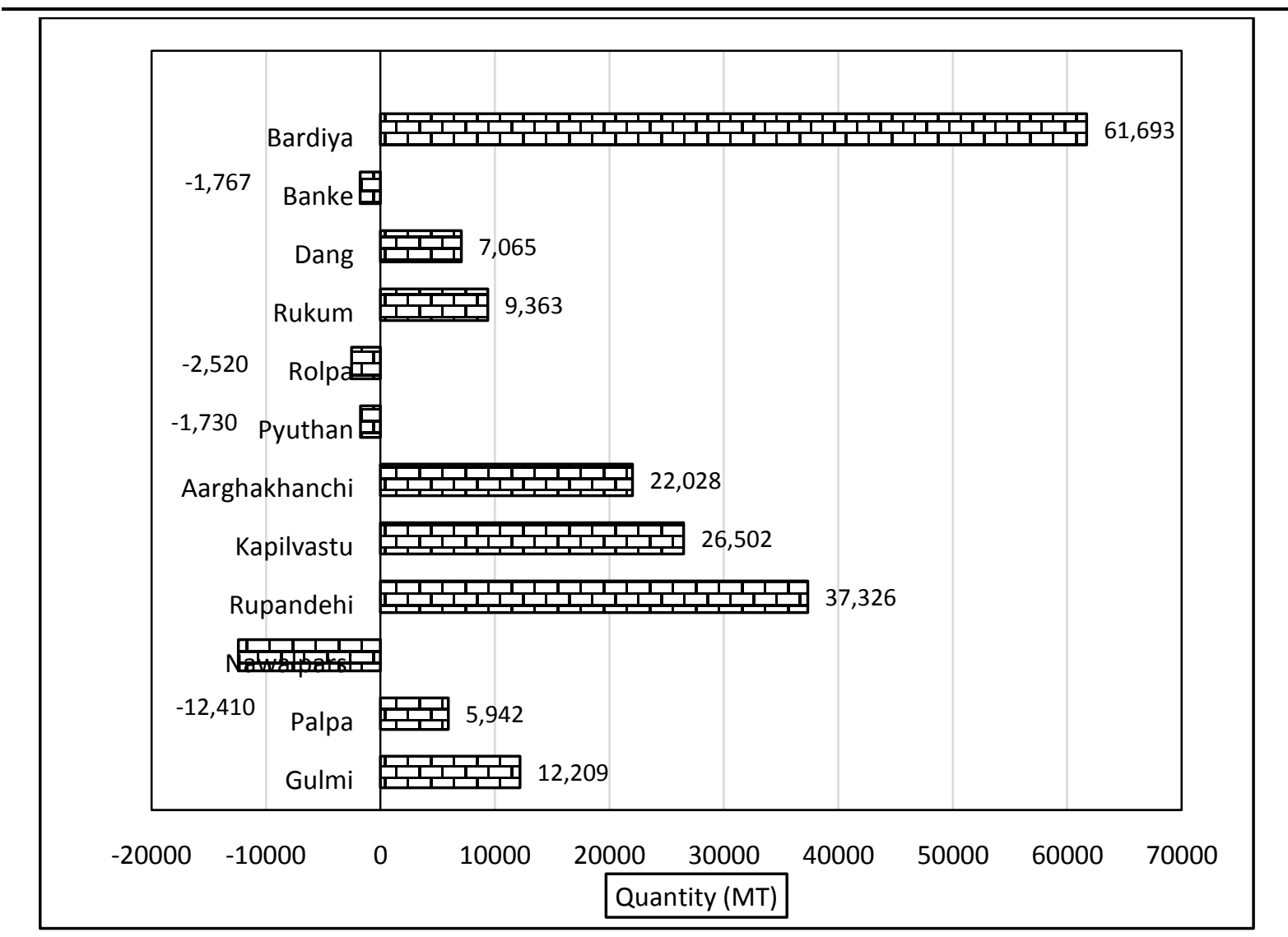

Figure 4.Food balance by district, 2015/16.

\section{CONCLuSion}

Agriculture is the major source of income and employment. This state has contributed about 14.8 percent of the total GDP of the country in 2011. Out of the total agricultural production of the country, this state's agriculture sectors, except fishing, has shared 18.4 percent (NPC 2014). Except two districts (Kapilvastu and Rupandehi), the area of agriculture land of the ten districts is below 20 percent of the total district area. Out of the total agricultural land, around five percent land in each district, except in Gulmi and Aarghakhanchi, is under permanent crops. Paddy is the major cereal and it shares about fifty percent of the total cereal production of the state. Maize, wheat and millet are other cereal crops. There are a few cash crops such as coffee, sugarcane, oilseeds, potato and ginger. The productivity of crops is varied by district. Paddy has the highest productivity in Palpa, maize has the highest in Rupandehi, and wheat has its highest productivity in Bardiya.

In terms of food production, there is food balance at state level. However, at district level a few districts such as Banke, Rolpa, Pyuthan and Nawalparasi have negative food balance. This state has ample opportunity of increasing food production and specialization of production by developing agricultural pocket areas. In this context, the Tarai district have ample opportunity of increasing production and productivity of cereal crops primarily paddy, wheat, maize and oilseeds. In addition sugarcane can be cultivated at larger scale. Irrigation and timely availability of agricultural inputs are essential. The underground water irrigation scheme can be developed. In Hill areas, in addition to cereals, cash crops and vegetable pocket areas can be developed.

\section{REFERENCES}

APROSC (1995), Nepal agriculture perspective plan (1995/96 - 2014/15). Kathmandu: Agricultural Projects Services Center and John Mellor Associates, Inc. Washington, D. C.

CBS. (Central Bureau of Statistics) (2012). National population and housing census 2011 (National Report). Kathmandu: Central Bureau of Statistics.

CBS. (2013). National sample census of agriculture Nepal 2011/12. Kathmandu: National Sample Census of Agriculture Nepal 2011/12. (http://cbs.gov.np/sectoral_statistics/agriculture/district_summary).

CBS.(2017). Population of 753 local unit. Kathmandu: Central Bureau of Statistics. (http://cbs.gov.np/sectoral_statistics/population/Population\%20of\%20744\%20Local\%20Bodies) 
FAO (2010). Assessment of Food Security and Nutrition Situation in Nepal. Pulchok (Lalitpur): Food and Agriculture Organization of the United Nations. (file://C:/Users/prem/Downloads/nutrition-situation.pdf access on September10, 2017).

Mannion, A.M. (1995). Agriculture and environmental change: Temporal and spatial dimension. Chichester: John Wiley and Sons.

MoAD. (Ministry of Agricultural Development) (2017). Statistical information on Nepalese agriculture. Kathmandu: Ministry of Agricultural Development, GoN.

MoF (Ministry of Finance) (2017). Budget speech of fiscal year 2017/18. Kathmandu: Ministry of Finance, Government of

Nepal. (http://www.mof.gov.np/uploads/document/file/Budget_Speech_207475_20170530011441.pdf accessed on September14, 2017).

NPC (2014). Nepal Human Development Report 2014. Kathmandu: National Planning Commission (NPC) Government of Nepal.

Robinson, G. (2004). Geography of agriculture: Globalization, restructuring and sustainability. Harlow:Pearson Education Limited.

Subedi, K.D. and K.C. Bhim. (2001). Food Security Situation in Nepal: Causes and Opportunities. Invited paper presented in the Workshop "Food Security in Nepal". 30 June, 2001, Kathmandu, Nepal. Organized by Agriculture Concern Society (ACS), Nepal.

Citation: P. S. Chapagain, "Agriculture Production and Food Security in State Number Five, Nepal ", International Journal of Research in Environmental Science, vol. 4, no. 1, p. 76-82, 2018. http://dx.doi.org/10.20431/2454-9444.0401010

Copyright: (C) 2018 Authors. This is an open-access article distributed under the terms of the Creative Commons Attribution License, which permits unrestricted use, distribution, and reproduction in any medium, provided the original author and source are credited. 